\section{Korrigierte Normwerte für das Serum-ACE durch Genotypisierung eines Deletions-/Insertions- Polymorphismus des ACE-Gens}

B. Ruprecht ${ }^{1}$, M. Schürmann², M. W. Ziegenhagen', E. vom Bauer ${ }^{3}$, D. Meier ${ }^{4}$, M. Schlaak', J. Müller-Quernheim ${ }^{1}$

${ }^{1}$ Forschungszentrum Borstel, Medizinische Klinik (Leiter: Prof. Dr. P. Zabel)

2 Medizinische Universität Lübeck, Institut für Humangenetik (Leiter: Prof. Dr. E. Schwinger)

${ }^{3}$ Gemeinschaftspraxis Dr. Kramer und Kollegen, Geesthacht

${ }^{4}$ Bühlmann Laboratories AG, Schönenbuch (Schweiz)
Zusammenfassung: Hintergrund: Die Serum-Aktivität des angiotensinkonvertierenden Enzyms (ACE) gilt als wichtiger Aktivitätsparameter der Sarkoidose. Für das ACE-Gen ist seit 1990 ein Deletions-/Insertions-(D/I)Genpolymorphismus bekannt. Die Serum-ACE-Werte korrelieren mit dem Genotyp dieses Polymorphismus. Homozygote für die Deletion (DD) weisen die höchsten Werte auf, Homozygote für die Insertion (II) die niedrigsten, die Werte der Heterozygoten (DI) liegen dazwischen. Das Maß der Beeinflussung der ACE-Aktivität durch den Genpolymorphismus differiert in Populationen unterschiedlicher ethnischer Herkunft. Erstmals wurden anhand der Bestimmungen bei einem größeren Kollektiv gesunder Personen aus Norddeutschland genotypkorrigierte Normalbereiche für die hiesige Population erstellt. Methodik: Bei 262 gesunden Personen wurde mittels einer PCR-Methodik aus genomischer DNA der Genotyp des ACE-D/I-Genpolymorphismus bestimmt und die ACE-Aktivität im Serum mittels eines kinetischen Tests gemessen. Ergebnisse: Bei $29,4 \%$ der untersuchten Personen liegt der Genotyp DD, bei $49,6 \%$ DI und bei $21,0 \%$ II vor. Eine vergleichbare Verteilung der Genotypen war auch in früheren Untersuchungen bei gesunden Mitteleuropäern gefunden worden. Die mittlere Serum-ACE-Aktivität (95\%-Konfidenzintervall) liegt beim Genotyp DD bei 59,8 U/I (31,8-87,8), beim Genotyp DI bei $47,7 \mathrm{U} / \mathrm{I}(18,6-76,8)$ und beim Genotyp II bei $32,2 \mathrm{U} / \mathrm{I}$ (13,7-50,7). Ohne Genotyp-Korrektur liegt der Mittelwert bei $48,0 \mathrm{U} / \mathrm{I}(15,0-80,9)$. Die Unterschiede zwischen den drei Genotypgruppen sind jeweils hochsignifikant $(p<0,0001)$. Schlussfolgerung: Die einmalige Bestimmung des Deletions-/Insertions-Polymorphismus des ACE-Gens und die Anwendung neuer genotypkorrigierter Normbereiche erlaubt eine bessere Interpretation der gemessenen ACE-Aktivität im Serum.

Corrected normal values for serum ACE by genotyping the deletion-|insertion-polymorphism of the ACE gene: Background: In sarcoidosis, serum ACE is widely recognised as a marker of disease activity. Since 1990 a deletion-/insertion polymorphism of the ACE gene is known and a correlation between the genotypes of this polymorphism and serum ACE levels has been observed. Homzygotes for the deletion allele (DD) have the highest levels and homozygotes for the insertion allele (II) the lowest. Heterozygote (DI) persons show intermediate levels. The extent of this influence varies in populations of different ethnic origin. In a large cohort of healthy individuals

Pneumologie 2001; 55: 326-332

(c) Georg Thieme Verlag Stuttgart · New York ISSN 0934-8387 from North of Germany, genotype-based normal ranges for serum ACE were determined for the population of Germany for the first time. Methods: In 262 healthy individuals the genotype of the ACE D/I gene polymorphism was determined from genomic DNA by a PCR method. In addition, in serum samples of all these individuals ACE level was measured with a kinetic test. Results: The genotype DD was found in $29.4 \%$ of the individuals examined, the genotype DI in $49.6 \%$ and the genotype II in $21.0 \%$, respectively. These results are similar to those found in previous investigations in other populations of Central European origin. The mean serum ACE levels (95\% confidence interval) in individuals with the genotypes DD, DI and II are $59.8 \mathrm{U} / \mathrm{I}$ (31.8-87.8), 47.7 U/I (18.6-76.8) and 32.2 U/I (13.7-50.7), respectively. Without taking the genotype into account, the average value is $48.0 \mathrm{U} / \mathrm{l}$ (15.0-80.9). Differences between all genotype groups are highly significant $(p<0.0001)$. Conclusions: In sarcoidosis patients, the determination of this ACE gene polymorphism once in the course of the disease allows a better interpretation of the serum ACE levels measured.

\section{Einleitung}

Die Sarkoidose ist eine systemische granulomatöse Erkrankung unklarer Ätiologie. Überwiegend werden Lunge und lymphatisches System befallen, jedoch kann fast jedes Organsystem betroffen sein. Gerade auch im Hinblick auf die sehr unterschiedlichen Verlaufsformen der Erkrankung sind in den letzten Jahren eine große Zahl klinischer, immunologischer und biochemischer Parameter untersucht worden, um die Krankheitsaktivität beurteilen zu können bzw. die Prognose der Erkrankung einzuschätzen [1]. Eine Erhöhung der Serumaktivität des angiotensinkonvertierenden Enzyms bei der Sarkoidose wurde 1975 erstmalig durch Liebermann beschrieben [2]. Inzwischen ist dieses Enzym einer der verbreitetsten und am besten untersuchten laborchemischen Aktivitätsparameter dieser Erkrankung [3-5]. Weitere Serumparameter, wie die Serum-Adenosindesaminase, das Neopterin und der lösliche Interleukin-2-Rezeptor, sind beschrieben und finden zur Aktivitätsbeurteilung der Sarkoidose ebenfalls Verwendung $[1,6]$. Allerdings wird eine Erhöhung des ACE nicht nur bei der Sarkoidose gesehen, sondern in unterschiedlichem Ausmaß auch bei anderen granulomatösen (z.B. Berylliose, seltener bei Tuberkulose und bei Lepra) und nichtgranulomatösen (z. B. Morbus Gaucher, Hyperthyreose, Diabetes mellitus mit proliferativer Retinopathie) Erkrankungen [7,8]. 
Das angiotensinkonvertierende Enzym (ACE; EC 3.4.15.1) ist eine Zink-Metalloproteinase, die hauptsächlich die Abspaltung carboxyterminaler Dipeptide von Oligopeptiden katalysiert [9-11]. Wichtigste physiologische Funktionen sind die Umwandlung von Angiotensin I zu Angiotensin II und die Inaktivierung von Bradykinin [12,13]. Das Hormon existiert in zwei Isoformen, einer somatischen und einer testikulären. Exprimiert wird die somatische Isoform insbesondere von vaskulären Endothelzellen, absorbierenden Epithelien, neuroepithelialen Zellen und von Zellen des Monozyten-Makrophagen-Systems [13-15]. Als Ursache für die Erhöhung der Aktivität dieses Enzyms bei der Sarkoidose wird eine verstärkte Produktion durch Epitheloidzellen in den Granulomen und durch Alveolarmakrophagen verantwortlich gemacht $[16,8]$. Die ACE-Aktivität reflektiert somit die Granulomlast des Körpers [17,18].

Es ist schon seit längerer Zeit bekannt, dass die Aktivität des Enzyms beim Gesunden zwar interindividuell eine sehr große Schwankungsbreite (bis um den Faktor 5,7) aufweist, intraindividuell jedoch sehr konstant ist. In einer französischen Untersuchung (Nancy-Studie) wurde 1988 eine familiäre Abhängigkeit der ACE-Aktivität gefunden [19]. Aus diesen Beobachtungen wurde geschlossen, dass die Höhe der ACE-Aktivität zumindest teilweise genetisch determiniert sein muss. 1990 wies die Arbeitsgruppe um Rigat einen Deletions-/ Insertions- (D/I-)Polymorphismus des ACE-Gens nach, mit dem ein Teil der interindividuellen Variabilität zu erklären ist [20]. Zwischen dem Genotyp dieses Polymorphismus und der Höhe der ACE-Aktivität besteht eine deutliche Assoziation. Personen, die homozygot für das D-Allel sind, weisen die höchsten ACE-Aktivitäten auf und Homozygote für das I-Allel die niedrigsten Aktivitäten. Heterozygote liegen mit ihren Aktivitäten dazwischen. Die Deletion bzw. Insertion betrifft eine 287 Basenpaare lange Sequenz vom sog. Alu-Typ im Bereich des Intron 16 des ACE-Gens (Basenpaare 14094 bis 14381 der Sequenz [21]).

Ursprünglich wurde errechnet, dass dieser Genpolymorphismus für $47 \%$ der Varianz der ACE-Aktivität verantwortlich sei [20]. Durch weitere Familienuntersuchungen in Populationen unterschiedlicher ethnischer Herkunft konnte nachgewiesen werden, dass weitere Gen-Loci Einfluss auf die Höhe der ACEWerte haben müssen (Quantitative Trait Loci; QTL). Das Maß der Beeinflussung der ACE-Aktivität durch diese verschiedenen Genorte differiert offensichtlich erheblich zwischen Gruppen unterschiedlichen ethnischen Ursprungs. Auch die Anzahl der beeinflussenden Gen-Loci scheint zwischen verschiedenen Ethnien zu differieren. Unter Berücksichtigung dieser anderen QTL wird der Einfluss des ACE-D/I-Genpolymorphismus auf die Varianz der ACE-Aktivität lediglich noch mit $9 \%$ bis $28 \%$, je nach Herkunft des Kollektivs, angegeben [22 - 24], wobei er bei Kaukasiern offensichtlich am höchsten ist. Der Mechanismus, über den dieser Genpolymorphismus die ACE-Aktivität beeinflusst, ist bisher unbekannt, da er einen nicht-transkribierten Abschnitt in einem Intron dieses Gens betrifft. Es ist deswegen wahrscheinlich, dass weniger der D/I-Polymorphismus selbst, sondern vielmehr eine andere genetische Variante, die (zumindest bei Kaukasiern) in starker Allelassoziation zu diesem Polymorphismus steht, für die beobachtete Varianz verantwortlich ist [24]. Wegen des oben beschriebenen, unterschiedlich stark ausgeprägten Einflusses dieses Genpolymorphismus auf die ACE-Aktivität in Gruppen verschiedener ethnischer Herkunft wurde angeregt, für unterschiedliche Populationen jeweils eigene genotypkorrigierte Normalbereiche zu ermitteln [25].

Zielsetzung dieser Untersuchung ist es, anhand der Daten eines ausreichend großen Normalkollektivs erstmalig für die kaukasische Population Deutschlands genotypkorrigierte Normalbereiche für die ACE-Aktivität zu ermitteln.

\section{Materialien und Methoden}

\section{Untersuchungskollektive}

In diese Untersuchung eingeschlossen wurden 262 gesunde, nicht blutsverwandte Personen (89 männlich, 173 weiblich; Alter: 37,4 $\pm 11,6$ Jahre). Bei den untersuchten Personen handelt es sich um Mitarbeiter des Forschungszentrums Borstel, die sich im Rahmen einer betriebsärztlichen Untersuchung freiwillig zu einer Blutspende bereit erklärt hatten. Alle waren vom Betriebsarzt als gesund eingestuft worden. Keiner und keine erhielt eine Medikation mit einem ACE-Hemmer. Alle untersuchten Personen sind kaukasischen Ursprungs.

\section{Bestimmung der Aktivität des ACE im Serum}

Die Aktivität des angiotensinkonvertierenden Enzyms (ACE) im Serum wurde mittels eines kinetischen Tests (BÜHLMANN ACE Kinetic kit, Bühlmann Laboratories, Schönenbuch, Schweiz) bestimmt. Bis zur Bestimmung wurden die Serumproben bei $-70^{\circ} \mathrm{C}$ aufbewahrt.

\section{Bestimmung der beiden Genpolymorphismen}

Der Genotyp des ACE-D/I-Genpolymorphismus wurde aus genomischer DNA mittels einer Polymerase-KettenreaktionsTechnik (PCR) bestimmt. Nach Separierung von Blutgranulozyten aus Heparin- bzw. EDTA-Blut erfolgte die Isolierung der DNA aus diesen mit Hilfe von TRIZOL-Reagenz (Firma GIBCO BRL, Grand Island, USA) entsprechend der Anleitung des Herstellers. Bis zur Durchführung der PCR wurden die DNAProben bei $-20^{\circ} \mathrm{C}$ aufbewahrt. Als Startermoleküle für die PCR fungieren zwei die Insertionsstelle flankierende DNA-Oligonukleotide. Dadurch entstehen, je nachdem, ob die Insertion oder die Deletion vorliegt, unterschiedlich lange DNA-Sequenzen. Dies verdeutlicht die Abb. 1.

Als Oligonukleotid-Primer für die Bestimmung dieses Polymorphismus werden diejenigen benutzt, die Rigat u. Mitarb. [26] in der Erstbeschreibung einsetzten (1. Primer: 5' CTG GAG ACC ACT CCC ATC CTT TCT 3', 2. Primer: 5' GAT GTG GCC ATC ACA TTC GTC AGA T 3'; Bezugsquelle: Firma MWGBiotech AG, Ebersberg). Pro Probe wurden $25 \mu$ l Reaktionslösung angesetzt, hierin enthalten sind jeweils $100 \mathrm{ng}$ genomische DNA, je 5 pmol beider Primer, 2,5 mmol/1 Magnesiumchlorid $\left(\mathrm{MgCl}_{2}\right), 0,2 \mathrm{mmol} / \mathrm{l}$ jedes der vier Desoxyribonukleosidtriphosphate (dNTP), 0,5 U Taq DNA-Polymerase (Firma GIBCO BRL, s.o.) und 2,5 $\mu$ l des dazugehörigen 10x-Puffers (ohne Magnesium) der gleichen Firma. Im Thermocycler (Personal Cycler, Firma Biometra, Göttingen) erfolgten (nach einer 270 Sekunden langen initialen Denaturierung bei $95^{\circ} \mathrm{C}$ ) 30 Zyklen zur Vervielfältigung der DNA, jeweils bestehend aus 30 Sekunden Denaturierung bei $94^{\circ} \mathrm{C}$, 30 Sekunden Primer-Anlagerung („annealing“) bei $54^{\circ} \mathrm{C}$ und 60 Sekunden 


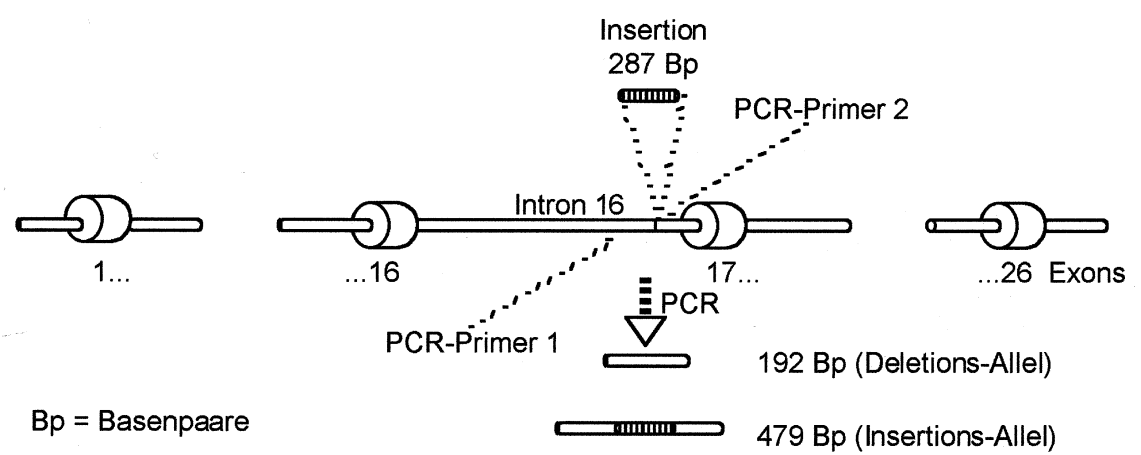

Abb. 1 Schematische Darstellung des ACEDeletions-/Insertions-Genpolymorphismus und seiner Bestimmung mittels PCR (abgewandelt nach [41]).

Primer-Verlängerung (DNA-Synthese, „extension“) bei $72^{\circ} \mathrm{C}$. Am Ende der PCR steht noch ein abschließender SyntheseSchritt („final extension“) von 600 Sekunden bei $72^{\circ} \mathrm{C} .10 \mu \mathrm{l}$ der PCR-Produkte wurden dann auf ein Agarose-Gel (2\% Agarose in TAE-Puffer [TRIS-Acetat EDTA]) aufgetragen und nach der Gel-Elektrophorese mit Ethidumbromid angefärbt. Unter UV-Licht werden dann die Banden für das DeletionsAllel (192 Basenpaare) bzw. für das Insertions-Allel (479 Basenpaare) sichtbar, so dass der Genotyp bestimmt werden kann. Die Ergebnisse wurden photographisch dokumentiert (Abb. 2).

Da es beschrieben ist, dass das Insertions-Allel bei dieser PCR gelegentlich nicht mit vervielfältigt wird [27], muss noch eine zweite PCR (mit einem Primer, der innerhalb der Insertion bindet) bei denjenigen Proben angeschlossen werden, die zunächst eine Homozygotie für das Deletions-Allel aufwiesen. Ein falsch negatives Ergebnis bezüglich des Insertions-Allels ist ansonsten möglich. Für diese PCR werden die Primer, die Odawarwa et al. beschreiben [28], benutzt (1. Primer: 5' TGG GAC CAC AGC GCC CGC CAC TAC 3'; 2. Primer: 5' TCG CCA GCC CTC CCA TGC CCA TAA 3', Bezugsquelle: Firma MWG-Biotech AG, s.o.). Der Reaktionsansatz unterscheidet sich von dem obigen dadurch, dass Dimethylsulfoxid (DMSO, Firma Sigma, s.o.) in einer Konzentration von $5 \%$ des Ansatzes zugesetzt wird, außerdem beträgt die Konzentration des $\mathrm{MgCl}_{2}$ $1,5 \mathrm{mmol} / \mathrm{l}$. Diese PCR läuft mit folgenden Temperaturen und Zeiten ab: 270 Sekunden initiale Denaturierung bei $95^{\circ} \mathrm{C}, 30$ Zyklen bestehend aus 30 Sekunden Denaturierung bei $94^{\circ} \mathrm{C}$,

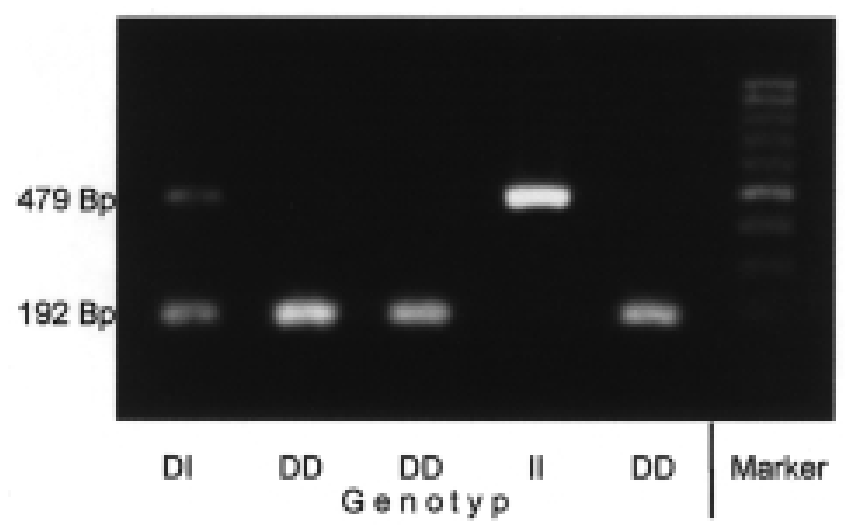

Abb. 2 Ausschnitt aus der Fotografie eines Gels mit Produkten der PCR für den Deletions-/Insertions-Polymorphismus des ACE-Gens.
45 Sekunden Primer-Anlagerung bei $62{ }^{\circ} \mathrm{C}$ und 40 Sekunden Primer-Verlängerung bei $72^{\circ} \mathrm{C}$. Den Abschluss bildete eine 300 Sekunden dauernde Synthese-Phase bei $72^{\circ} \mathrm{C}$. Falls das Insertions-Allel vorhanden ist, kann nach der Gel-Elektrophorese ein Produkt von 335 Basenpaaren dargestellt werden.

\section{Statistische Analysen}

Vergleiche zwischen nominal skalierten Parametern (Allelund Genotypverteilung) erfolgten nach dem $\chi^{2}$-Test. Für den Vergleich kontinuierlicher Parameter (ACE-Wert) wurde der verteilungsunabhängige U-Test nach Mann und Whitney angewandt. Eine Signifikanz gilt als erreicht, wenn die Fehlerwahrscheinlichkeit bei $\mathrm{p}<0,05$ liegt. Die Ergebnisse werden als Mittelwert \pm eine Standardabweichung angegeben.

Für die durch unser Normalkollektiv definierten Normbereiche der ACE-Aktivität im Serum wurden die 95\%-Konfidenzintervalle bestimmt, entsprechend dem Mittelwert plus/minus das 1,96fache der Standardabweichung.

\section{Ergebnisse}

\section{Genotyp- und Allel-Verteilung}

Von den 262 untersuchten gesunden Personen wiesen 77 (29,4\%) den Genotyp DD, 130 (49,6\%) den heterozygoten Typ DI und 55 (21,0\%) den Typ II auf. Das Verhältnis von D-Allel zu I-Allel beträgt 0,542 zu 0,458 (Abb.3). Eine geringe Häufung des Genotyp DI bei den untersuchten Männern (55,1\% gegenüber $46,8 \%$ bei den weiblichen Probanden) und ein entsprechend selteneres Vorkommen des Genotyp DD bei Männern (22,5\% gegenüber $32,9 \%$ bei Frauen) ist jeweils statistisch nicht signifikant $(p>0,05)$. Die beobachtete Genotyp-Verteilung befindet sich im Einklang mit dem Hardy-WeinbergGesetz.

\section{Aktivität des ACE im Serum im Normalkollektiv}

Die mittlere ACE-Aktivität lag bei den Personen mit dem Genotyp DD bei $59,8 \pm 14,4 \mathrm{U}$, beim Genotyp DI bei $47,7 \pm 14,9 \mathrm{U}$ und beim Genotyp II bei 32,2 $\pm 9,5 \mathrm{U}$. Die Unterschiede zwischen den drei Genotyp-Gruppen sind jeweils hoch signifikant $(p<0,0001)$. Ohne Berücksichtigung des Genotyps liegt der mittlere ACE-Wert bei 48,0 $\pm 16,8 \mathrm{U}$. Tendenziell zeigt sich bei den untersuchten Männern ein niedrigeres ACE (46,4 $\mathrm{U}$ gegenüber $51,1 \mathrm{U}$ bei den Frauen). Im Gesamtkollektiv ist dieser Unterschied nicht signifikant, aller- 


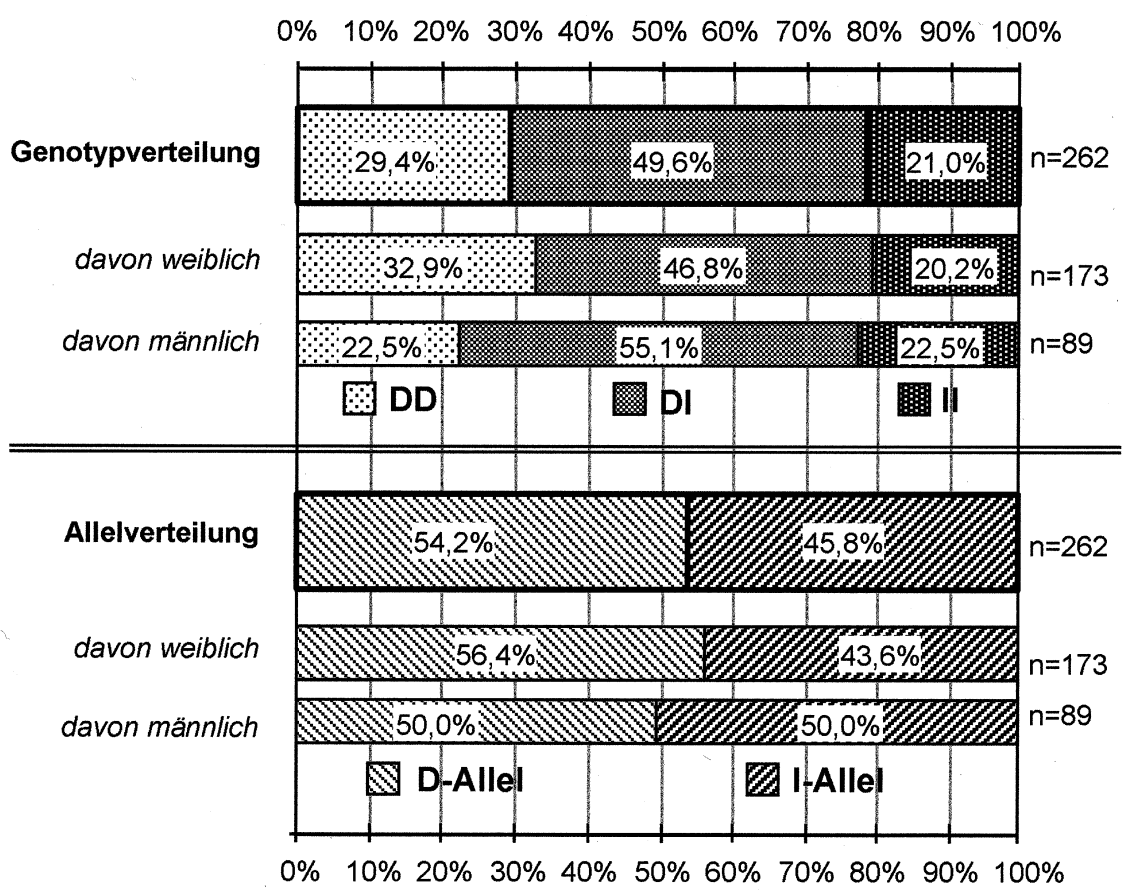

Abb. 3 Verteilung der Genotypen und der Allele des ACE-Deletions-/Insertions-Genpolymorphismus im Normalkollektiv.

dings erreicht er in den Genotyp-Gruppen DI und II Signifikanzniveau (Tab.1). Eine Altersabhängigkeit der ACE-Aktivität besteht in dem untersuchten Kollektiv (17 bis 64 Jahre) nicht. Der mittlere ACE-Wert liegt in der Altersgruppe zwischen 17 und 30 Jahren bei $48,0 \pm 16,4 \mathrm{U}(\mathrm{n}=77)$, in der Gruppe zwischen 31 und 45 Jahren bei $47,6 \pm 16,3 \mathrm{U}(\mathrm{n}=118)$ und in der Gruppe zwischen 46 und 64 Jahren bei $48,3 \pm 17,9 \mathrm{U}$ $(\mathrm{n}=67)$.

Bezogen auf 95\%-Konfidenzintervall ergibt sich für den Genotyp DD ein Normalbereich von 31,8 bis $87,8 \mathrm{U}$, für den heterozygoten Typ DI von 18,6 bis 76,8 U und für den Typ II von 13,7 bis 50,7 U. Ohne Genotyp-Korrektur liegt der Normbereich zwischen 15,0 und 80,9 U (Abb. 4).

Zur Überprüfung der Genauigkeit der Methodik wurden bei 35 Personen die Bestimmungen der ACE-Aktivität durch zwei Laboratorien parallel durchgeführt, die Abweichung der beiden Messungen voneinander betrug maximal 6\%. Ein Trend in eine Richtung bestand nicht. Zusätzlich wurde überprüft, ob die Probenlagerung einen Einfluss auf die gemessene ACEAktivität haben könnte. Eine einzelne Arbeit von 1984 [29] hatte eine Erhöhung der ACE-Aktivität im Serum bei Proben gefunden, die bei $-70^{\circ} \mathrm{C}$ tiefgefroren wurden, im Vergleich zum Einfrieren bei $-20^{\circ} \mathrm{C}$. Beim Vergleich von zwei zeitnah abgenommenen Proben von 16 Personen, die einmal bei $70^{\circ} \mathrm{C}$ und einmal bei $-20^{\circ} \mathrm{C}$ tiefgefroren wurden, konnte kein richtungsweisender Trend bezüglich der Veränderung der ACE-Aktivität festgestellt werden (bei 7 Personen Erhöhung, bei 8 Personen Verminderung der ACE-Aktivität, bei einer identische Werte).

\section{Diskussion}

Die vorgelegte Untersuchung weist für eine Stichprobe der gesunden Population kaukasischen Ursprungs in Deutschland eine Korrelation zwischen der Aktivität des ACE im Serum und den Genotypen des Deletions-/Insertions-Polymorphismus des ACE-Gens nach. Bei den Personen mit dem Genotyp DD liegt die höchste ACE-Aktivität im Serum vor, bei denen mit dem Genotyp II die niedrigste. Die Heterozygoten liegen mit ihren Werten dazwischen. Die Unterschiede der ACEAktivität sind zwischen allen drei Genotyp-Gruppen jeweils hochsignifikant $(\mathrm{p}<0,0001)$. Mit 262 Personen, die auf diesen Polymorphismus hin untersucht werden konnten, und zwischen 55 und 130 Personen in den einzelnen GenotypGruppen, ist dieses Kollektiv hinreichend groß, damit die Messungen als repräsentativ gelten können. Der Schwankungsbereich der gemessenen Werte in diesem gesunden Kollektiv liegt bei dem Faktor 5,3. Er entspricht damit in etwa dem in der Einleitung erwähnten Literaturwert von 5,7, der so (bzw. in vergleichbaren Rahmen) von mehreren Untersuchern gefunden wurde $[2,19,30]$. Die Verteilung der Genotypen und der Allele entspricht den Beobachtungen anderer Untersucher bei Kaukasiern (Übersicht in [31]). Durch die Anwendung der zweiten, insertionsspezifischen, PCR kann praktisch ausgeschlossen werden, dass das I-Allel wegen fehlender Vervielfältigung in der ersten PCR zu selten gefunden wird [27], wie dies bei einigen älteren Untersuchungen zu beobachten war [28]. Bei einer routinemäßigen Bestimmung des Genpolymorphismus ist die zweite PCR notwendig, um falsch negative Befunde für das I-Allel auszuschließen. Bei 134 DNA-Proben, die ohne die Kontrolluntersuchung als homozygot für die Deletion (DD) eingestuft worden waren, wurde in sechs Fällen durch diese zweite Untersuchung erkannt, dass der heterozygote Genotyp DI vorliegt.

Vergleiche unserer Ergebnisse bezüglich der ACE-Aktivität mit anderen Untersuchungen sind äußerst schwierig. In unterschiedlichen Laboratorien werden verschiedene Methoden zur Bestimmung der Enzymaktivität mit sehr stark differierenden Normalbereichen angewandt. Diese Normbereiche lassen sich nicht unbedingt linear umrechnen. Selbst bei Anwendung der gleichen Methodik ergeben sich aufgrund 


\begin{tabular}{|c|c|c|c|}
\hline & Anzahl & Alter & sACE \\
\hline Gesamtkollektiv & 262 & $37,4 \pm 11,6$ & $48,0 \pm 16,8$ \\
\hline davon männl. & $89(34,0 \%)$ & $38,7 \pm 11,2$ & $51,1 \pm 17,2$ \\
\hline davon weibl. & 173 (66,0\%) & $36,7 \pm 11,8^{\text {n.s. }}$ & $46,4 \pm 16,5^{\text {n.s. }}$ \\
\hline \multicolumn{4}{|l|}{ Genotypen } \\
\hline DD & $77(29,4 \%)$ & $39,6 \pm 12,3$ & $59,8 \pm 14,4$ \\
\hline männl. & 20 (22,5\%) & $40,7 \pm 11,7$ & $65,7 \pm 14,6$ \\
\hline weibl. & $57(32,9 \%)^{\text {n.s. }}$ & $39,2 \pm 12,5$ & $57,8 \pm 13,9^{\text {n.s. }}$ \\
\hline DI & $130(49,6 \%)$ & $35,5 \pm 11,2$ & $47,7 \pm 14,9$ \\
\hline männl. & $49(55,1 \%)$ & $37,2 \pm 11,5$ & $52,3 \pm 15,4$ \\
\hline weibl. & $81(46,8 \%)^{\text {n.s. }}$ & $34,3 \pm 11,0$ & $44,9 \pm 14,0^{(p=0,008)}$ \\
\hline II & $55(21,0 \%)$ & $38,7 \pm 11,3$ & $32,2 \pm 9,5$ \\
\hline männl. & $20(22,5 \%)$ & $40,7 \pm 10,4$ & $35,2 \pm 8,0$ \\
\hline weibl. & $35(20,2 \%)^{\text {n.s. }}$ & $37,6 \pm 11,7$ & $30,6 \pm 10,1^{(p=0,024)}$ \\
\hline \multicolumn{4}{|l|}{ Allele } \\
\hline D-Allel & $284(54,2 \%)$ & & \\
\hline männl. & 89 (50\%) & & \\
\hline weibl. & $195(56,4 \%)^{\text {n.s. }}$ & & \\
\hline I-Allel & $240(45,8 \%)$ & & \\
\hline männl. & 89 (50\%) & & \\
\hline weibl. & $151(43,6 \%)^{\text {n.s. }}$ & & \\
\hline
\end{tabular}

Tab. 1 ACE-Deletions-/Insertions-Genpolymorphismus im Normalkollektiv und dessen Einfluss auf die ACE-Aktivität im Serum.

Die angegebenen Signifikanzniveaus beziehen sich auf die festgestellten Unterschiede zwischen männlichen und weiblichen Personen.

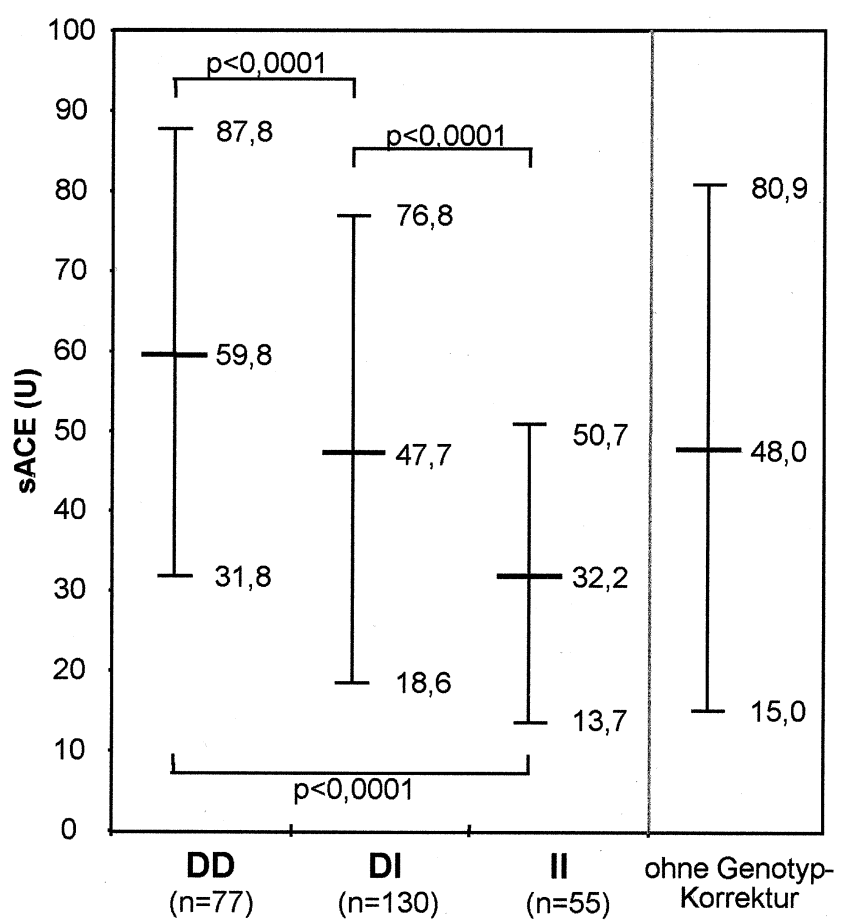

Abb. 4 Genotyp-korrigierte Normbereiche für das ACE im Serum. Angegeben werden der jeweilige Mittelwert für die einzelnen Genotypen (DD, DI und II) sowie das 95\%-Konfidenzintervall (entsprechend $\mu \pm 1,96 \sigma$ ). Im Vergleich dazu der Normbereich, der sich ohne Anwendung der Genotyp-Korrektur in dem untersuchten Kollektiv ergibt. bestimmter technischer Unterschiede teilweise deutlich differierende Ergebnisse, speziell auch bei dem hier angewandten kinetischen Test [32]. Verglichen mit einer Untersuchung in England an 146 gesunden Personen [25] sind die Relationen der Ergebnisse der einzelnen Genotyp-Gruppen zueinander vergleichbar. Auch dort sind die Unterschiede der ACE-Werte zwischen den drei Gruppen hochsignifikant. Eine Untersuchung bei 314 gesunden Japanern fand ebenfalls hochsignifikante Unterschiede der ACE-Werte zwischen den drei Genotypen [33], genauso eine ähnlich große zweite Studie dort [34]. Ein Vergleich der Daten dieser zweiten Untersuchung mit gesunden Individuen aus Finnland und Schweden, deren Proben im selben Labor unter den selben Bedingungen gemessen wurden (unpublizierte Daten, zitiert bei [35]) zeigte, dass deren ACE-Aktivitäten, besonders beim Genotyp II, geringer waren als die der Japaner. Für Populationen schwarzafrikanischen Ursprungs liegen bisher wenig Daten vor, eine Studie [36] an Kindern und Heranwachsenden konnte nur minimale Unterschiede bezüglich der ACE-Aktivität zwischen den einzelnen Genotyp-Gruppen ohne jegliche Signifikanz nachweisen.

Diese unterschiedlichen Ergebnisse bestätigen die in der Einleitung zitierten Beobachtungen aus Familienuntersuchungen, dass der Einfluss des D/I-Genpolymorphismus auf die Aktivität des ACE in verschiedenen Populationen unterschiedlich stark ausgeprägt ist. Die Wichtigkeit regional bestimmter genotypkorrigierter Normbereiche für die ACEAktivität im Serum, wie sie von Sharma [25] angeregt wurde, wird durch diese Beobachtungen eindrucksvoll unterstrichen. Nur so lässt sich eine validere Einschätzung der gemessenen ACE-Aktivitäten erreichen. Mit der vorliegenden Untersu- 
chung wird für unsere Population erstmals ein solcher genotypkorrigierter Normbereich erstellt. Durch die Anwendung dieser genotypkorrigierten Normalbereiche wird der Faktor, um den die ACE-Werte beim Gesunden schwanken, im hiesigen Kollektiv von 5,3 auf Werte zwischen 2,8 (Genotyp DD) und 4,1 (Genotyp DI) reduziert.

Bei dieser Untersuchung fällt auf, dass die ACE-Werte der Männer höher sind als die der Frauen, und zwar unabhängig vom Genotyp. Ähnliche Beobachtungen machten auch andere Untersucher $[4,19,37]$. Anderswo wird dies jedoch nicht bestätigt [8]. Plausible Erklärungen für diese Geschlechtsdifferenz lassen sich in der Literatur nicht finden, möglicherweise spielen hier auch hormonelle Einflüsse mit eine Rolle. Bei der fehlenden Signifikanz des Unterschiedes im Gesamtkollektiv halten wir diese Differenz insgesamt für zu gering, um die genotypkorrigierten Normalbereiche weiter nach dem Geschlecht zu differenzieren. Ein zusätzlicher diagnostischer Gewinn erscheint dadurch nicht gegeben. Das Fehlen einer Altersabhängigkeit der ACE-Aktivität deckt sich mit den Beobachtungen anderer Untersucher bei Erwachsenen [14]. Bei Kindern wurde dort eine erhöhte ACE-Aktivität gemessen. Die Anwendung der genotypkorrigierten Normalbereiche ist daher in dieser Altersgruppe noch nicht möglich.

Die publizierten Normwerte des hier benutzten Tests zur kinetischen Messung des ACE liegen zwischen 18 und $55 \mathrm{U}$. Damit liegt der obere Grenzwert deutlich niedriger als in der hiesigen Untersuchung. Geringe, zufällige Verschiebungen der Genotypen in den untersuchten Normalkollektiven mit einer Erhöhung der Häufigkeit des Insertions-Allels und Verminderung der Frequenz des Deletions-Allels, stellen eine plausible Erklärung für diese beobachtete Differenz dar. Eine definitive Klärung wäre nur über eine nachträgliche Genotyp-Überprüfung der untersuchten Personen zu erreichen. Eine Reihe von Autoren hat darauf aufmerksam gemacht, dass neben den absoluten Werten für die Aktivität des ACE im Serum auch die Schwankungen innerhalb des Normalbereiches bei der Beurteilung der Erkrankungsaktivität von Sarkoidose-Patientinnen und -Patienten wichtig ist [4,38-40]. Diese Beobachtungen deuten bereits auf die Problematik der oberen Grenze des Normbereiches bei den beträchtlichen interindividuellen Schwankungen der ACE-Aktivität hin, die mit der Nutzung der genotypkorrigierten Normalwerte an Gewicht verliert.

Als Fazit ist festzustellen, dass derselbe Zusammenhang zwischen Genotyp des Deletions-/Insertions-Polymorphismus des ACE-Gens und der gemessenen ACE-Aktivität, der schon in anderen Kollektiven kaukasischer Herkunft gesehen wurde, auch in der gesunden Bevölkerung Deutschlands besteht. Die Nutzung der hier ermittelten genotypkorrigierter Normalbereiche für die ACE-Aktivität erlaubt eine bessere Differenzierung zwischen normalen und pathologisch veränderten Werten. Wir empfehlen daher die einmalige routinemäßige Bestimmung im Rahmen der Sarkoidose-Diagnostik, die dann die Anwendung der genotypkorrigierten Normbereiche erlaubt.

\section{Danksagung}

Die Autoren danken Herrn Dr. R. Dostatni von der Fa. DPC Biermann in Bad Nauheim für die Bereitstellung der Untersuchungs-Kits für die ACE-Bestimmungen.

\section{Literatur}

${ }^{1}$ Müller-Quernheim J. Serum markers for the staging of disease activity of sarcoidosis and other interstitial lung diseases of unknown etiology. Sarcoidosis Vasc Diffuse Lung Dis 1998; 15 : $22-37$

${ }^{2}$ Lieberman J. Elevation of serum angiotensin-converting-enzyme (ACE) level in sarcoidosis. Am J Med 1975; 59: 365- 372

${ }^{3}$ Hunninghake GW, Costabel U, Ando M, Baughman R, Cordier JF, du Bois R, Eklund A, Kitaichi M, Lynch J, Rizzato G, Rose C, Selroos O, Semenzato G, Sharma OP. ATS/ERS/WASOG statement on sarcoidosis. Sarcoidosis Vasc Diffuse Lung Dis 1999; 16: 149173

${ }^{4}$ Lieberman J, Nosal A, Schlessner A, Sastre-Foken A. Serum angiotensin-converting enzyme for diagnosis and therapeutic evaluation of sarcoidosis. Am Rev Respir Dis 1979; 120: 329 335

${ }^{5}$ Meeting Report. Consensus conference: activity of sarcoidosis. Third WASOG meeting, Los Angeles, USA, September 8 - 11, 1993. Eur Respir J 1994; 7: 624-627

${ }^{6}$ Wetzel E, Müller-Quernheim J, Lorenz J. Die SerumAdenosindesaminase als Aktivitätsparameter der Sarkoidose. Pneumologie 1999; 53: 323 - 328

${ }^{7}$ Lieberman J. Angiotensin-Converting Enzyme in Nonpulmonary Sarcoidosis. Sem Resp Med 1992; 13: 399-401

${ }^{8}$ Rohatgi PK. Serum angiotensin converting enzyme in pulmonary disease. Lung 1982; 160: 287-301

${ }^{9}$ Beneteau-Burnat B, Baudin B. Angiotensin-converting enzyme: clinical applications and laboratory investigations on serum and other biological fluids. Crit Rev Clin Lab Sci 1991; 28: 337-356

${ }^{10}$ Hooper NM. Angiotensin converting enzyme: implications from molecular biology for its physiological functions. Int J Biochem 1991; 23: 641 - 647

${ }^{11}$ Skidgel RA, Erdos EG. The broad substrate specificity of human angiotensin I converting enzyme. Clin Exp Hypertens (A) 1987; 9: 243-259

12 Ehlers MRW, Riordan JF. Angiotensin-converting enzyme: new concepts concerning its biological role. Biochemistry 1989; 28 : $5311-5318$

${ }^{13}$ Soubrier F, Hubert C, Testut P, Nadaud S, Alhenc-Gelas F, Corvol P. Molecular biology of the angiotensin I converting enzyme: I. Biochemistry and structure of the gene. J Hypertens 1993; 11: $471-476$

${ }^{14}$ Costerousse O, Allegrini J, Lopez M, Alhenc-Gelas F. Angiotensin I-converting enzyme in human circulating mononuclear cells: genetic polymorphism of expression in T-lymphocytes. Biochem J 1993; 290: $33-40$

${ }^{15}$ Sibony M, Gasc JM, Soubrier F, Alhenc-Gelas F, Corvol P. Gene expression and tissue localization of the two isoforms of angiotensin I converting enzyme. Hypertension 1993; 21: 827 835

${ }^{16}$ Pertschuk LP, Silverstein E, Friedland J. Immunohistologic diagnosis of sarcoidosis. Detection of angiotensin-converting enzyme in sarcoid granulomas. Am J Clin Pathol 1981; 75: 350 - 354

${ }^{17}$ Gilbert S, Steinbrech DS, Landas SK, Hunninghake GW. Amounts of angiotensin-converting enzyme mRNA reflect the burden of granulomas in granulomatous lung disease. Am Rev Respir Dis 1993; 148: $483-486$

${ }^{18}$ Muthuswamy PP, Lopez-Majano V, Ranginwala M, Trainor WD. Serum angiotensin-converting enzyme (SACE) activity as an indicator of total body granuloma load and prognosis in sarcoidosis. Sarcoidosis 1987; 4: $142-148$

${ }^{19}$ Cambien F, Alhenc-Gelas F, Herbeth B, Andre JL, Rakotovao R, Gonzales MF, Allegrini J, Bloch C. Familial resemblance of plasma angiotensin-converting enzyme level: the Nancy Study. Am J Hum Genet 1988; 43: $774-780$ 
${ }^{20}$ Rigat B, Hubert C, Alhenc-Gelas F, Cambien F, Corvol P, Soubrier F. An insertion/deletion polymorphism in the angiotensin Iconverting enzyme gene accounting for half the variance of serum enzyme levels. J Clin Invest 1990; 86: 1343-1346

${ }^{21}$ Rieder MJ, Taylor SL, Clark AG, Nickerson DA. Sequence variation in the human angiotensin converting enzyme. Nat Genet 1999; 22: $59-62$

${ }^{22}$ Harrap SB, Davidson HR, Connor JM, Soubrier F, Corvol P, Fraser R, Foy CJ, Watt GC. The angiotensin I converting enzyme gene and predisposition to high blood pressure. Hypertension 1993; 21: $455-460$

${ }^{23}$ McKenzie CA, Julier C, Forrester T, McFarlane-Anderson N, Keavney B, Lathrop GM, Ratcliffe PJ, Farrall M. Segregation and linkage analysis of serum angiotensin I-converting enzyme levels: evidence for two quantitative-trait loci. Am J Hum Genet 1995; 57: 1426 - 1435

24 Tiret L, Rigat B, Visvikis S, Breda C, Corvol P, Cambien F, Soubrier F. Evidence, from combined segregation and linkage analysis, that a variant of the angiotensin I-converting enzyme (ACE) gene controls plasma ACE levels. Am J Hum Genet 1992; 51: 197-205

${ }^{25}$ Sharma P, Smith I, Maguire G, Stewart S, Shneerson J, Brown MJ. Clinical value of ACE genotyping in diagnosis of sarcoidosis. Lancet 1997; 349: 1602-1603

${ }^{26}$ Rigat B, Hubert C, Corvol P, Soubrier F. PCR detection of the insertion/deletion polymorphism of the human angiotensin converting enzyme gene (DCP1) (dipeptidyl carboxypeptidase 1). Nucleic Acids Res 1992; 20: 1433

27 Shanmugam V, Sell KW, Saha BK. Mistyping ACE heterozygotes. PCR Methods Appl 1993; 3: 120-121

28 Odawara M, Matsunuma A, Yamashita K. Mistyping frequency of the angiotensin-converting enzyme gene polymorphism and an improved method for its avoidance. Hum Genet 1997; 100: $163-166$

${ }^{29}$ Pietili S, Koivula T. Increase of serum angiotensin-converting enzyme activity after freezing. Scand J Clin Lab Invest 1984; 44: $453-455$

${ }^{30}$ Beneteau B, Baudin B, Morgant G, Giboudeau J, Baumann FC. Automated kinetic assay of angiotensin-converting enzyme in serum. Clin Chem 1986; 32: 884-886

${ }^{31}$ Staessen JA, Ginocchio G, Wang JG, Saavedra AP, Soubrier F, Vlietinck R, Fagard R. Genetic variability in the renin-angiotensin system: prevalence of alleles and genotypes. J Cardiovasc Risk 1997; 4: $401-422$

32 Maguire GA, Price CP. A continuous monitoring spectrophotometric method for the measurement of angiotensin-converting enzyme in human serum. Ann Clin Biochem 1985; 22: 204-210

${ }^{33}$ Tomita H, Ina Y, Sugiura Y, Sato S, Kawaguchi H, Morishita M, Yamamoto M, Ueda R. Polymorphism in the angiotensinconverting enzyme (ACE) gene and sarcoidosis. Am J Respir Crit Care Med 1997; 156: $255-259$

${ }^{34}$ Furuya K, Yamaguchi E, Itoh A, Hizawa N, Ohnuma N, Kojima J, Kodama N, Kawahami Y. Deletion polymorphism in the angiotensin I converting enzyme (ACE) gene as a genetic risk factor for sarcoidosis. Thorax 1996; 51: 777-780

${ }^{35}$ Kawakami Y, Munakata M, Yamaguchi E, Furuya K, Matsuda T. Molecular studies of bronchial asthma, sarcoidosis and angiotensin converting enzyme inhibitor-induced cough. Respirology 1998; 3: $45-49$

${ }^{36}$ Bloem LJ, Manatunga AK, Pratt JH. Racial difference in the relationship of an angiotensin I-converting enzyme gene polymorphism to serum angiotensin I-converting enzyme activity. Hypertension 1996; 27: $62-66$

${ }^{37}$ Hurst PL, Lovell-Smith CJ. Optimized assay for serum angiotensin-converting enzyme activity. Clin Chem 1981; 27: 20482052
${ }^{38}$ Ainslie GM, Benatar SR. Serum angiotensin converting enzyme in sarcoidosis: sensitivity and specificity in diagnosis: correlations with disease activity, duration, extra-thoracic involvement, radiographic type and therapy. QJ Med 1985; 55: 253-270

${ }^{39}$ DeRemee AS, Rohrbach MS. Normal serum angiotensin converting enzyme activity in patients with newly diagnosed sarcoidosis. Chest 1984; 85: 45-48

${ }^{40}$ Strausz J, Muller-Quernheim J, Ferlinz R. Serumspiegel des sezernierten Interleukin-2 Rezeptor als ein Aktivitätsparameter der Sarkoidose. Dtsch Med Wochenschr 1989; 114: 744- 749

${ }^{41}$ Morris BJ. Hypothesis: an angiotensin converting enzyme genotype, present in one in three caucasians, is associated with increased mortality rate. Clin Exp Pharmacol Physiol 1996; 23: $1-10$

\section{Dr. med. B. Ruprecht}

Medizinische Klinik

Forschungszentrum Borstel

Parkallee 35

23845 Borstel

E-mail: brup@fz-borstel.de 